\title{
Effectiveness, Problems and Expectations of British Educational Assistance
}

\author{
Ziwei Jiang \\ Lingnan Normal University, Zhanjiang, China \\ Email: jiangziwei.yes@foxmail.com
}

How to cite this paper: Jiang, Z.W. (2019) Effectiveness, Problems and Expectations of British Educational Assistance. Open Journal of Social Sciences, 7, 191-196. https://doi.org/10.4236/jss.2019.77017

Received: May 17, 2019

Accepted: July 21, 2019

Published: July 24, 2019

Copyright $\odot 2019$ by author(s) and Scientific Research Publishing Inc. This work is licensed under the Creative Commons Attribution International License (CC BY 4.0).

http://creativecommons.org/licenses/by/4.0/

\section{c) (i) Open Access}

\begin{abstract}
Britain is an exporter of education. It is committed to helping poor developing countries improve the backward education situation. It has achieved remarkable results in infrastructure construction, material supply and personnel training. At present, the development of education aid in Britain has entered a new five-year planning period, and the direction of aid has changed accordingly. It has increased the support for girls' education, improved the effectiveness of education aid funds, and strengthened the management mode of aid cooperation. Starting with the development of educational aid in Britain, this study analyzed the effectiveness and problems of educational aid, and prospected the development trend of educational aid in Britain from the aspects of aid quality, international cooperation, policy adjustment and girls' education.
\end{abstract}

\section{Keywords}

Educational Assistance, Educational Development, Infrastructure

\section{Introduction}

Britain is a leader in international development assistance. After World War II, the focus of British government's assistance has shifted to helping poor developing countries, improving people's living environment and quality, and activating the internal driving force of economic development of recipient countries through funds allocation, material distribution and facilities construction. In this process, Britain's international aid system is becoming more and more perfect with remarkable achievements [1]. The United States Brookings Institution and the Center for Global Development Research published a joint assessment report, pointing out that "Britain is superior to other countries in terms of aid effectiveness, aid regulation and transparency", and has made great contributions 
to the well-being of the world's people, national interests, international strategic deployment and restructuring of the world pattern. In the long run, education assistance can train talents and reserve human capital for the recipient countries, which is the driving force for the recipient countries to get rid of poverty and sustainable development. Since 1997, British education assistance has focused on basic education, supporting the infrastructure construction of schools in recipient countries, strengthening teacher training, paying attention to children's schooling at the basic education stage, and paying attention to the quality and effectiveness of education assistance [2]. By 2015, the UK had exceeded its commitment to international education assistance and had excelled in terms of the number of aid recipients, infrastructure facilities and ways of cooperation. Since then, the United Kingdom has ushered in a new five-year aid plan and taken new measures aimed at consolidating existing achievements, adjusting the direction of aid and improving aid effectiveness [3].

\section{Effectiveness of British Educational Assistance}

Educational aid is one of the priorities of British aid. By the end of 2012, Britain had provided education assistance to 149 developing countries in the world. For poor developing countries, financial support and infrastructure improvement can only alleviate the superficial "symptoms" of the weakness of the recipient countries, and the key to solve the "crux" lies in the investment in education, the training of teachers and the accumulation of talents [4]. In recent years, with the trend of international aid, the focus of British education assistance has changed from higher education and continuing education to basic education, and at the same time, the emphasis on early childhood education has been increased.

\subsection{Effectiveness of the Implementation of the Millennium Development Goals}

In education assistance, the British government will focus on basic education, care for children's growth and girls' education, pay attention to students' enrolment rate and quality of education, and attach importance to the role of the new Millennium Development Goals. In 2009, the United Kingdom included the Millennium Development Goals in the policy text of Eradicating World Poverty: Building Our Common Future. At the same time, in the Global Education Cooperation Project, Goal 2: Universal Primary Education and Goal 3: Promoting Gender Equality and Empowering Women are included in the Millennium Development Goals, and it is proposed that "by 2015, all children will be able to complete primary school curriculum education". To achieve this goal, we need all parties to work hard, not only to ensure the supply of infrastructure and materials, but also to strengthen technical guidance and skills training. In 2015, the UK Department for International Development released a report entitled Government Policies 2010-2015: Education in Developing Countries. The report summarizes the implementation of the previous five-year plan, which mentioned 
that every child should have the opportunity to go to school. Not only to ensure that they can enter the classroom, but also to let them accept good teaching, but also learning to change their lives, to get more opportunities [5].

\subsection{Fulfilling the Commitment of Educational Assistance}

In 2011, the British Aid: Changing Life and Successful was issued to guide the development of British educational aid and to make commitments in terms of students' schooling, aid cooperation, teacher training and infrastructure construction. After five years of aid development, the international performance of British education assistance not only over fulfilled its task, promoted the education development of recipient countries and children, but also introduced new teaching technology, provided electronic education resources and expanded the audience of education assistance.

In order to help more young people get close to education, get education and fulfill the UK's educational aid commitments, the UK government has introduced distance education and online courses into the development process of educational assistance. The development of "Linked Classroom 2012" project is one of its typical models. It promotes 5000 schools worldwide to form long-term cooperation and share educational resources. At present, in Britain, Africa, the Middle East and Asia, 30,000 schools have joined the online cooperative curriculum. About 28,000 teachers and 9000 principals have been trained, and their core skills and global citizenship teaching have been upgraded. Between 2015 and 2016, the UK Department for International Development supported 11.3 million pupils to enter primary and secondary schools, exceeding the previous commitment of 11 million. At the same time, the Ministry of International Development and multilateral cooperative organizations have achieved remarkable results in educational assistance activities. In 2014, UNICEF helped 10.4 million children enter primary education; from July 2014 to June 2015, with the support of the Global Education Cooperation Project, about 98,000 teachers were trained.

\section{Problems in British Educational Assistance}

\subsection{Millennium Development Goals Have Not Been Fully Achieved}

Over the past 10 years, due to the impact of the Millennium Development Goals, countries have increased investment in education and increased education budget in order to ensure that all children can complete all primary school curricula by 2015, but this still failed to achieve the original plan of the Millennium Development Goals. At present, 59 million marginalized children around the world drop out of school, and gender inequality still exists [6]. Critics argue that focusing on children's school attendance ignores the quality of education and reduces the value of aid funds. In 2015, the UK Department for International Development issued the Government Policy 2010-2015: Education in Developing Countries, which mentions that "250 million children worldwide have re- 
ceived education for more than four years", but they still fail to complete their studies and still do not read, write and arithmetic. The purpose of assistance is not only to ensure that they enter the classroom, but also to enable them to receive good teaching, and to change their lives through learning, so as to obtain more opportunities.

\subsection{Inefficient Use of Educational Aid Funds}

The UK Department for International Development, supported by the UK government's budget, has planned to invest 1 billion in education aid to three countries in eastern Africa over a 10-year period (2005-2015). Although the investment of funds has improved the lives of the poor people in the region and ensured the increase of enrollment, the quality of education is worrying. In 2012, the Independent Commission on Aid Impact issued a report on the DFID Education Project in the Three East African Countries, which clearly pointed out that although British aid expanded the financing of education systems in the three East African countries, the Department for International Development of the United Kingdom lacked attention to students' learning. According to the report, the poor quality of basic education in these countries has seriously affected the development of education assistance from the UK Department for International Development. At the same time, the UK Department for International Development only considers the basic conditions of learning, but does not consider whether teachers can normally attend classes and whether students can continue to receive education. If the majority of students cannot meet the basic standards of Chinese or mathematics, then the popularization of primary education cannot be achieved. At the same time, it also shows that British aid funds and national budget funds have not fully developed its value. In recent years, bilateral and multilateral donations around the world have also reflected this situation, and funding for education by the OECD ODA Committee is declining year by year.

\subsection{Ignoring the Educational Problems of Marginalized Girls}

Girls' education is mixed in the aid projects of the Department for International Development of the United Kingdom. The most obvious problem is the education of marginalized girls. In 2016, the Independent Commission on Aid Impact published a report entitled Opportunities, Maintenance and Success in Basic Education-British Aid Support for marginalized Girls: Performance Assessment, which pointed out that girls' education was easily neglected or forgotten in the development of aid projects. The reasons are as follows: firstly, girls' education goals have been replaced by other priorities for development; secondly, the Department for International Development of the United Kingdom lacks influence on education projects of recipient governments; thirdly, interventions concerning girls are not perfect, and there are no targets for marginalized girls, which restrict their ability to solve girls' education problems; fourthly, as part of 
assistance cooperation, Lack of professional knowledge or skills in girls' education; Fifth, the environment is challenging and difficult to implement.

In assessing assistance projects, it was found that girls' assistance should take into account not only marginalization, but also the actual situation or the impact of the political environment. For example, the Girls' Education Challenge project in Kenya is an online learning assistance project, which mainly provides electronic media for marginalized girls to help them learn through the media. However, due to geographical conditions, it is greatly limited, because there are places where electricity cannot be supplied and electronic media cannot be introduced. In fact, there are still many such failed projects, which can neither achieve the pre-set goals nor benefit recipient countries. In addition, in 2015, the UK Department for International Development released an assessment of the implementation of the Girls' Education Challenge project. The evaluation found that the participation, learning and sustainability of the UK Girls Education Challenge project in the implementation process were not good, and the interventions formulated could not meet the training requirements of girls, nor could they meet the expected language and mathematics standards [7].

\section{UK Educational Aid Expectations}

By 2015, Britain had overfulfilled its education aid mission and started its next five-year plan. In February 2016, the UK Department for International Development issued the Independent Sector Plan, which plans the next five-year (2016-2020) education assistance plan and defines the strategic objectives of UK international assistance. In view of the problems existing in the development of education assistance, the plan reiterates the importance of girls' and women's education, and emphasizes the need to expand new channels of assistance, strengthen international cooperation, reform the budget, respond to humanitarian crises and achieve its aid commitments. In May 2016, Britain again pointed out to strengthen cooperation with international organizations to address education in crisis situations at the World Humanitarian Summit. The summit also launched the "Education Can't Wait" fund project, which clearly stipulates that all countries should strengthen their joint efforts to achieve the development goals of "by the end of 2020, 13.6 million young people living in crisis situations will have a good education; by 2030, all young people in crisis situations will have a good education". Generally speaking, there are five trends in the future development of British educational aid. That is, the restriction and loosening of aid policy, unified management and effective cooperation, to achieve $0.7 \%$ of the aid budget, the application of the "results-expenditure" system and further promote girls' education.

\section{Conclusions}

Over the past few decades, British educational aid has achieved remarkable results. The British government has made continuous efforts to increase aid funds, 
strengthen girls' education, optimize the allocation of resources, adjust international cooperation relations and so on. It has achieved remarkable results in fulfilling the promises of education assistance one by one. At the same time, over the years, Britain's aid trend has been synchronized with the development trend of international aid. Participation in and continuous promotion of international cooperation projects have become the development impetus of international cooperation projects.

Although Britain's performance in the development of education assistance is worthy of recognition, there are also some problems such as poor quality of education, inefficient use of funds, and blind spots in the development of girls' education in the donor countries. This is also the direction of improvement in the development of international assistance in the next five years. At the United Nations General Assembly in 2015, Britain made a new commitment to "let no one fall behind: our commitment", which became a new strategy for Britain's aid development in the next five years. The new strategic initiatives will focus on the three core concepts of equality, priority and humanism, pursue equality of opportunity for all, give priority to the development of disadvantaged groups, let everyone receive education, ensure the quality of education, and strive to realize personal values. Standing at a new starting point of development, Britain's renewed commitment to international aid will make more people wait and see. The new strategic initiatives will focus on the three core concepts of equality, priority and humanism, pursue equality of opportunity for all, give priority to the development of disadvantaged groups, and let everyone receive education, ensure the quality of education, and strive to realize personal values.

\section{Conflicts of Interest}

The author declares no conflicts of interest regarding the publication of this paper.

\section{References}

[1] Lin, Y. and Yao, L. (2018) Analysis of British International Education Assistance. Operations and Management, No. 4, 157-160.

[2] Wang, X., Zheng, H. and Liu, W. (2017) Overview and Evaluation of British Educational Aid Development. World Education Information, No. 14, 53-58.

[3] Niu, C. (2009) Research on Entrepreneurship Education in British Universities. Xuelin Press, Shanghai.

[4] Zhao, F. (2016) British Educational Donation Foundation and College Cooperative Training Assistant. World Education Information, No. 24, 74.

[5] Hu, X. (2011) Research on International Educational Assistance and Its Effect. East China Normal University, Shanghai.

[6] Hang, C. (2010) Research on British Black Africa Policy of Hangcong McMillan Government. Graduate School of Chinese Academy of Social Sciences, Beijing.

[7] Xiong, L. (2017) Britain Announced the Latest Education and Skills Measures. World Education Information, No. 22, 77-78. 